\title{
Analisis Eksistensi Kearifan Lokal Huyula Desa Bongoime Provinsi Gorontalo
}

\section{Existence analysis of Huyula local Wisdom Bongoime Village Gorontalo Province}

\author{
Faris Budiman Annas ${ }^{1}$, Ekawati Sri Wahyuni ${ }^{1}$ \\ ${ }^{1}$ Departemen Sains Komunikasi dan Pengembangan Masyarakat, \\ Fakultas Ekologi Manusia, Institut Pertanian Bogor, Bogor
}

\begin{abstract}
This study aims to analyze the existence of local wisdom Huyula measured by knowledge, attitudes and behavior of farmers to Huyula and its relationship with the internal and external factors farmers. The sample was Bongoime villagers who work as rice farmers. This study uses quantitative data with qualitative data furnished. This study tested using Spearman rank correlation test with significance level 0,05 level. Results of this study indicate that Huyula is a values contained in the mutual aid society. Farmers have the high knowledge, attitude and behavior towards Huyula although in practice only in the cleaning of irrigation channels. There is a relationship between knowledge, attitudes and behavior of farmers toward Huyula. There are two variabel like age and extention intensity that affects the existence Huyula.
\end{abstract}

Keywords: economic behavior, fisher, fisheries industrialization

\begin{abstract}
Abstrak
Penelitian ini bertujuan untuk menganalisis keberadaan kearifan lokal Huyula diukur dengan pengetahuan, sikap dan perilaku petani untuk Huyula dan hubungannya dengan petani internal dan faktor eksternal. Sampel adalah Bongoime desa yang bekerja sebagai petani padi. Penelitian ini menggunakan data kuantitatif dengan dilengkapi data kualitatif. Penelitian ini diuji menggunakan uji korelasi rank Spearman dengan taraf signifikansi 0,05. Hasil penelitian ini menunjukkan bahwa Huyula adalah nilai-nilai yang terkandung dalam masyarakat saling membantu. Petani memiliki pengetahuan yang tinggi, sikap dan perilaku terhadap Huyula walaupun dalam prakteknya hanya dalam pembersihan saluran irigasi. Ada hubungan antara pengetahuan, sikap dan perilaku petani terhadap Huyula. Ada dua variabel seperti usia dan extention intensitas yang mempengaruhi keberadaan Huyula.
\end{abstract}

Kata kunci: perilaku ekonomi, nelayan, industrialisasi perikanan

\section{Pendahuluan}

Indonesia merupakan negara agraris dengan masyarakatnya yang sebagian besar bermata pencaharian sebagai petani. Sejak 1945, pertanian di Indonesia umumnya masih bersifat subsisten atau tradisional, mereka melakukan usaha pertanian dengan mengandalkan pengetahuan yang mereka miliki. Pengetahuan tersebut diperoleh secara turun temurun melalui tradisi ataupun komunikasi verbal. Dewasa ini kesadaran akan perlunya kearifan lokal mendapat perhatian yang lebih besar dari para ilmuwan dipicu oleh adanya wacana global tentang kegagalan pembangunan dinegara-negara dunia ketiga. Hal ini dikarenakan oleh semakin merosotnya kualitas lingkungan alam akibat semakin cepatnya kepunahan pengetahuan-pengetahuan yang menjadi basis adaptasi berbagai komunitas lokal. Selain itu, perlunya penguatan terhadap kebutuhan akan jatidiri di tengah arus globalisasi perlu ditingkatkan (Ahimsa, 2008)

Terdapat dua poin penting dalam kearifan lokal, yakni pengetahuan dan praktek yang tidak lain adalah pola interaksi dan pola tindakan. Pengetahuan dapat disamakan dengan knowledge yang dapat diperoleh dari berbagai sumber seperti media massa ataupun dari cerita orang lain sehingga dapat mudah dilupakan, sedangkan pengalaman akan lebih bersifat permanen terutama berkaitan dengan pengalaman langsung dalam perjalanan hidup manusia (Sairin, 2006)

Kearifan lokal pada masyarakat memegang peranan yang penting dalam pengelolaan sumberdaya alam. Pentingnya kearifan lokal pada masayarakat dilihat dari proses interaksi warga masyarakat yang sejak beberapa generasi telah hidup dari pengelolaan 
sumber daya alam (Sirait, 2005). Ketersediaan, kelestarian dan juga keberlanjutan sumberdaya alam ditentukan oleh adanya faktor kearifan sebagai manifestasi akal masyarakat lokal yang tersembunyi dan diyakini sebagai sesuatu yang benar, dapat dirasakan bersama, serta merupakan sesuatu yang baik dan berguna bagi kehidupannya.

Pentingnya mengkaji kearifan lokal terutama di bidang pertanian, merupakan isu penting di negara yang sedang berkembang seperti Indonesia. Sejarah dari nusantara membuktikan bahwa negara ini kaya akan kearifan lokal pada bidang pertanian dan pengolahan bahan makanan. Huyula sebagai salah satu bentuk kearifan lokal yang ada di Gorontalo merupakan rangkaian nilai-nilai yang terdapat dimasyarakat yang melandasi sistem gotong royong. Penelitian ini dilakukan untuk dapat mengetahui eksistensi kearifan lokal Huyula di dalam masyarakat Gorontalo.

Penelitian ini bertujuan untuk dapat mendeskripsikan bentuk-bentuk kearifan lokal berupa Huyula dalam pengelolaan sumberdaya pertanian sawah yang terdapat pada kelompok tani. Menganalisis eksistensi kearifan lokal Huyula dalam pengelolaan sumberdaya pertanian sawah yang diukur dari aspek pengetahuan, sikap, dan perilaku petani. Menganalisis hubungan antara faktor internal dan eksternal petani terhadap eksistensi kearifan lokal Huyula dalam pengelolaan sumberdaya pertanian padi sawah.

\section{Metode Penelitian}

Responden dari penelitian ini adalah warga Desa Bongoime yang berprofesi sebagai seorang petani tanaman padi sawah. Kerangka sampling dalam penelitian ini adalah gabungan dari enam kelompok tani, sehingga kerangka sampling terdiri dari 176 petani padi sawah. Teknik pengambilan sampel dilakukan dari setiap kelompok tani tersebut diambil tujuh sampel petani secara acak, sehingga diperoleh 42 sampel petani padi sawah.

Jenis data yang dikumpulkan dalam penelitian ini adalah data primer dan data sekunder. Data primer kuantitatif diperoleh dari hasil wawancara terstruktur dengan menggunakan instrumen berupa kuesioner yang terdiri dari pertanyaan tertutup Selain itu, pengumpulan data penelitian ini juga dilakukan melalui wawancara mendalam dengan beberapa tokoh masyarakat seperti kepala desa, pangggoba, penyuluh pertanian, dan ketua kelompok tani untuk mengkaji eksistensi kearifan lokal Huyula.

Data yang diperoleh dianalisis secara deskriptif analitis dan diperkuat dengan data kualitatif ditujukan untuk menggambarkan bagaimana karakteristik individu (khalayak). Selanjutnya hasil analisis diinterpretasikan untuk memperoleh suatu kesimpulan.Uji korelasi dengan Rank Spearman digunakan untuk melihat hubungan yang nyata antar variabel dengan data berbentuk ordinal, seperti untuk menguji hubungan antarakarakteristik individu seperti tingkat pendapatan (skala ordinal) dengan tingkat dengan tingkat pengetahuan, sikap dan perilaku (skala ordinal). Hubungan antara faktor internal dan faktor eksternal terhadap pengetahuan, sikap serta perilaku Huyula petani diuji dengan uji korelasi Rank Spearman. Uji korelasi rank Spearman digunakan untuk menentukan hubungan antara kedua variabel (variabel independen dan variabel dependen) yang ada pada penelitian ini, menguji hubungan antara usia, tingkat pendapatan, tingkat pendidikan, luas lahan garapan, pekerjaan non pertanian, dan intensitas penyuluhan terhadap tingkat pengetahuan, sikap dan juga perilaku yang

Tabel 1 Jumlah Umur dan Persentase Penduduk berdasarkan Jenis Pekerjaan

\begin{tabular}{lcc}
\hline \multicolumn{1}{c}{ Jenis Pekerjaan } & Jumlah (Jiwa) & Presentase (\%) \\
\hline Petani Pangan & 245 & 37,20 \\
Petani Perkebunan & 82 & 12,40 \\
Petani Peternakan & 166 & 25,20 \\
Nelayan & 2 & 0,30 \\
Tukang/Montir & 3 & 0,40 \\
Pedagang & 87 & 13,20 \\
PNS/TNI/POLRI & 72 & 10,90 \\
\hline Jumlah & 657 & 100,00 \\
\hline
\end{tabular}


Tabel 2 Karakteristik Petani

\begin{tabular}{lrrlrc}
\hline Karakteristik Petani & Jumlah & $\mathbf{( \% )}$ & Karakteristik Petani & Jumlah & (\%) \\
\hline Umur & & & Luas Lahan Garapan & & \\
Muda & 1 & 2 & Rendah & 16 & 38 \\
Dewasa & 26 & 62 & Sedang & 10 & 24 \\
Tua & 15 & 36 & Tinggi & 16 & 38 \\
Tingkat Pendidikan & & & $\begin{array}{l}\text { Kepemilikan pekerjaan } \\
\text { non pertanian }\end{array}$ & & \\
Rendah & 16 & 38 & Pertanian & 27 & 64 \\
Sedang & 10 & 24 & $\begin{array}{l}\text { Pertanian dan Non } \\
\text { Pertanian }\end{array}$ & 15 & 36 \\
Tinggi & 16 & 38 & & & \\
Tingkat Pendapatan & & & & & \\
Rendah & 26 & 63 & & & \\
Sedang & 2 & 5 & & & \\
Tinggi & 13 & 32 & & & \\
\hline
\end{tabular}

berkenaan dengan kearifan lokal Huyula dalam pengelolaan sumberdaya pertanian.

\section{Hasil dan Pembahasan}

Masyarakat di Desa Bongoime secara umum bermata pencaharian sebagai petani, yang digolongkan menjadi petani pangan, perkebunan dan peternakan. Petani pangan di wilayah Desa Bongoime seluruhnya mengandalkan irigasi teknis untuk pengairan sawah. Petani pangan terdiri dari petani padi sawah, jagung, ubi kayu, ubi jalar dan kacang tanah. Petani perkebunan terdiri dari petani kelapa dalam, dan petani peternakan terdiri dari peternak sapi, kambingm ayam buras dan itik. Terdapat sebesar 10,9\% dari keseluruhan masyarakat Desa Bongoime yang berprofesi sebagai PNS/TNI/POLRI, $13 \%$ berprofesi sebagai pedagang, $0,4 \%$ berprofesi sebagai montir dan terdapat nelayan sebanyak 2 orang.

Responden dalam penelitian ini memiliki karakteristikyangberagam, karakteristik responden dilihat dari umur, tingkat pendidikan, tingkat pendapatan, luas lahan garapan dan kepemilikan pekerjaan non pertanian. Karakteristik responden berdasarkan usia dibagi menjadi petani usia muda, dewasa dan tua, karakteristik responden berdasarkan tingkat pendapatan digolongkan menjadi tingkat pendapatan rendah, sedang, dan tinggi, karakteristik responden berdasarkan tingkat pendidikan digolongkan menjadi petani berpendidikan rendah, sedang, tinggi. Karakteristik responden berdasarkan luas lahan garapan digolongkan menjadi petani yang memiliki luas lahan garapan rendah, sedang dan tinggi. Karakteristik petani menurut berbagai kategori di atas dapat diamati pada Tabel 5

\section{Karakteristik Responden menurut Usia}

Usia adalah lamanya seseorang hidup yang dihitung semenjak ia lahir hingga ulang tahun terakhir sebelum penelitian ini dilakukan. Dalam penelitian ini, usia responden yang berupa petani padi sawah dibagi menjadi tiga yaitu petani muda (18-30 tahun), petani dewasa (31-50 tahun ) dan petani tua ( $>50$ tahun) (Havighurst 1950 dalam Mugnisieyah, 2006). Berdasarkan Tabel 5 menunjukkan bahwa dari 42 petani padi sawah, terdapat sebesar $2 \%$ (1 orang) responden yang termasuk ke dalam kategori petani muda, terdapat sebanyak $62 \%$ atau sebanyak 26 orang responden termasuk ke dalam kategori petani tua dan terdapat sebanyak 36\% (15 orang) yang termasuk ke dalam petani tua. Responden terbanyak berasal dari kategori petani dewasa dan jumlah responden terkecil berasal dari kategori petani muda.

\section{Karakteristik Responden menurut Tingkat Pendapatan}

Tingkat pendapatan responden adalah jumlah 
Tabel 3 Jumlah Responden Menurut Respon terhadap Pertanyaan Mengenai Pengetahuan Huyula

\begin{tabular}{lccc}
\hline \multicolumn{1}{c}{ Pertanyaan } & Tahu & $\begin{array}{c}\text { Tidak } \\
\text { Tahu }\end{array}$ & Total \\
\hline $\begin{array}{l}\text { Pengetahuan tentang Huyula secara umum yang berarti } \\
\text { bekerja bersama-sama }\end{array}$ & 100,0 & - & 100,0 \\
Pengetahuan tentang sistem Huyula dalam pengolahan lahan & 92,9 & 7,1 & 100,0 \\
Pengetahuan tentang sistem Huyula dalam penanaman padi & 92,9 & 7,1 & 100,0 \\
& & & \\
Pengetahuan tentang "Ti'ayo" dalam pengolahan lahan & 61,9 & 38,1 & 100,0 \\
Pengetahuan tentang "Ti'ayo" dalam penanaman padi & 61,9 & 38,1 & 100,0 \\
\hline
\end{tabular}

penghasilan secara keseluruhan dari hasil pertanian dalam setahun terakhir, ditambah dengan penghasilan sampingan (non-pertanian) yang diperoleh setiap bulan. Dalam penelitian ini pendapatan responden dikelompokkan menjadi tiga kategori yaitu sebagai berikut:

a) Tingkat pendapatan rendah (jika nilai penghasilan total berada di bawah rata-rata nilai pendapatan responden)

b) Tingkat pendapatan sedang (jika nilai penghasilan total sama dengan rata-rata pendapatan responden )

c) Tingkat pendapatan tinggi (jika nilai penghasilan total diatas rata-rata pendapatan responden)

Sebanyak 63\% (26 orang) responden yang termasuk ke dalam kategori pendapatan rendah, terdapat sebanyak 5\% (2 orang) responden termasuk ke dalam kategori pendapatan sedang dan terdapat sebanyak $32 \%$ (13 orang) yang termasuk ke dalam kategori pendapatan tinggi. Hal ini menunjukkan bahwa jumlah responden yang jumlah responden yang paling banyak dalam penelitian ini berasal dari petani padi sawah yang memiliki tingkat pendapatan rendah.

\section{Bentuk-bentuk Kearifan Lokal Huyula}

Huyula merupakan kerjasama sosial yang bersifat tanpa pamrih dan telah sejak dahulu dipraktekkan oleh para luluhur dan merupakan suatu bentuk sistem ekonomi yang terkoordinir maupun secara sukarela (Duludu, 2012). Pada masyarakat Desa Bongoime, nilai-nilai Huyula diterapkan oleh masyarakat dalam berbagai aspek kehidupan. Nilai- nilai Huyula diwujudkan dalam berbagai kegiatan misalnya dalam kerja bakti untuk pembersihan lingkungan pedesaan, pembuatan jalan desa, kematian, pembersihan saluran irigasi lokal maupun kegiatan pertanian. Kegiatan kerja bakti untuk kepentingan umum, dalam koordinasi dengan pemerintah setempat dengan tidak membedakan status sosialnya, kegiatan kerja bakti tersebut biasanya disebut sebagai kegiatan "Hulunga" oleh masyarakat.

\section{Nilai-nilai Huyula dalam Pertanian}

Nilai-nilai Huyula sebagai suatu bentuk kearifan lokal di Desa Bongoime merupakan salah satu solusi yang membantu petani dalam kaitannya dengan pengelolaan sumberdaya pertanian padi sawah. Dalam pengelolaan sumber daya pertanian khususnya pertanian padi sawah di Desa Bongoime nilai-nilai Huyula terbagi menjadi dua wujud yaitu kegiatan Huyula dan Ti'ayo. Kegiatan Huyula merupakan suatu sistem kerja sama dalam suatu kelompok dalam pengolahan lahan (pajeko) dan kegiatan penanaman. Kegiatan Huyula dapat diilustrasikan sebagai berikut, jika seorang petani memiliki luas lahan sawah sebesar satu pantango $(1$ pantango $=0,2 \mathrm{Ha})$, maka akan berusaha mencari 5-6 petani lainnya yang samasama ingin melakukan pengolahan lahan. Maka petani-petani tersebut berkumpul untuk membentuk kelompok kerja dan penentuan jumlah hari kerja. Jumlah hari kerja adalah total dari hari kerja dalam pengolahan lahan yang harus dilakukan oleh petanipetani tersebut. Jika petani yang terkumpul sebanyak enam orang maka biasanya jumlah hari kerjanya adalah enam hari. Selama enam hari itu, kelompok 
Tabel 4 Jumlah Responden Menurut Respon terhadap Pertanyaan Mengenai Sikap tentang Huyula

\begin{tabular}{lccccc}
\hline \multicolumn{1}{c}{ Pernyataan } & STS & TS & S & SS & Total \\
\hline $\begin{array}{l}\text { Saya senang/tertarik dengan sistem pengo- } \\
\text { lahan lahan secara Huyula }\end{array}$ & 4,8 & 33,3 & 47,6 & 14,3 & 100,0 \\
$\begin{array}{l}\text { Saya senang/tertarik dengan sistem penana- } \\
\text { man secara Huyula }\end{array}$ & 4,8 & 23,8 & 57,1 & 14,3 & 100,0 \\
$\begin{array}{l}\text { Pengolahan lahan saat ini dapat dilakukan } \\
\text { secara Huyula }\end{array}$ & 35,7 & 59,5 & 4,8 & - & 100,0 \\
$\begin{array}{l}\text { Penanaman padi dapat saat ini dilakukan } \\
\text { secara Huyula }\end{array}$ & 9,5 & 73,8 & 16,7 & - & 100,0 \\
\hline
\end{tabular}

kerja tersebut bergilir mengolah lahan (membajak) sawah dari petani yang mendapat giliran pertama hingga sawah terakhir yang dimiliki oleh petani. Setiap petani dalam kelompok kerja tersebut memperoleh jatah satu haripengolahan lahan yang dibantu oleh kelompok kerja. Dalam sistem Huyula tidak ada upah tenaga kerja, yang ada adalah sistem tenaga dibalas dengan tenaga. Biasanyanya bekal konsumsi dalam kegiatan kerja tersebut tergantung dari kesepakatan, ada pula kesepakatan membawa bekal masing-masing atau petani yang memiliki lahan yang sedang diolah yang memberikan bekal makanan dan bergiliran seterusnya. Fakta tersebut berdasarkan kutipan pernyataan responden berikut.

"Dulu sebelum ada traktor, kalo mau bapajeko, kita bapangge petani lain biar mo sama-sama bapajeko. Kalo so takumpul, baru torang baku ganti, hari ini torang sama-sama mau ba pajeko di petani yang satu, terus bergilir sampai semua sawah lo petani selesai mo pajeko, biasanya tiap orang dapat jatah satu hari pa orang itu pe sawah'. (Yamin Gani, $51 \mathrm{Th}$ )

"Dulu sebelum ada traktor. Jika ingin membajak sawah, saya biasanya memanggil petani lain untuk sama-sama membajak sawah. Jika sudah terkumpul, lalu kita bergiliran, hari ini kitasama-sama membajak sawah milik salah satu petani, kemudian bergilir hingga semua sawah milik petani yang ikut dalam Huyula ini selesai dibajak, satu orang petani biasanya mendapat jatah satu hary". (Yamin Gani, 51).
Berbeda dengan Huyula, Ti'ayo bersifat tidak terikat dan lebih mudah dilakukan karena petani yang mengajak petani lainnya yang merupakan teman, kerabat atau keluarganya tidak harus bekerja bergantian kepada petani yang telah membantunya. Orang-orang yang diudang untuk ber-"Ti'ayo" biasanya diberikan konsumsi berupa santapan siang sebagai tanda terimakasih atas bantuan orangorang tersebut. Fakta tersebut berdasarkan kutipan pernyataan:

"Dulu torang biasanya ada istilah Ti'ayo. Kalo kita mau ba pajeko pa kita pesawah, biasanya kita bapangge kita pe taman buat ba Ti’ayo. Gagah itu ba Ti’ayo itu, bisa mo bilang gratis. Cuma mau kase makan saja sama itu orang-orang yang babantu. Baru kalo ba Ti'ayo tidak ada keterikatan hari bekerja pa dorang pe sawah, soalnya ini biasa dibilang saling membantu. Beda dengan Huyula, Kalo Huyula torang musti kerja berhari-hari sesuai perjanjian, kalo torang sakit, torang musti cari pengganti buat kerja Huyula. Mar gagah juga itu Huyula bisa capat torang ba pajeko soalnya sama sama torang bakarjä'. (Kaita Bano, 57 Tahun).

"Dulu pernah ada istilah yang namanya Ti'ayo. Jadi jika kita ingin membajak sawah, biasanya kita mengajak teman atau kerabat untuk ber-Ti'ayo. Ti'ayo bagus sekali, karena sifatnya gratis. Kita hanya memberikan makanan saja kepada orangorang yang telah membantu. Tiay tidak ada keterikatan harus bekerja di sawah orang 
Tabel 5 Jumlah Responden Menurut Respon terhadap Pertanyaan Mengenai Perilaku tentang Huyula

\begin{tabular}{lcccccc}
\hline \multicolumn{1}{c}{ Pernyataan } & TP & P & J & S & SS & Total \\
\hline $\begin{array}{l}\text { Mengikuti kegiatan pembersihan saluran } \\
\text { irigasi dilakukan secara Huyula }\end{array}$ & 2,4 & 11,9 & 21,4 & 64,3 & - & 100,0 \\
& & & & & & \\
$\begin{array}{l}\text { Kegiatan pengolahan lahan dilakukan secara } \\
\text { Huyula }\end{array}$ & 14,3 & 85,7 & - & - & - & 100,0 \\
$\begin{array}{l}\text { Kegiatan penanaman padi dilakukan secara } \\
\text { Huyula }\end{array}$ & 14,3 & 85,7 & - & - & - & 100,0 \\
\hline
\end{tabular}

yang telah membantu. Berbedea dengan Huyula, kalo ber-Huyula kita harus bekerja hingga berhari-hari sesuai perjanjian, jika kita berhalangan karena sakit, kita musti mencari orang pengganti untuk berHuyula. Namun Keunggulan Huyula yaitu kegiatan pembajakan sawah dapat dilakukan dengan cepat karena dikerjakan bersama-sama’ (Kaita Bano, 57 Tahun)

\section{Pengetahuan, Sikap dan Perilaku Petani Terhadap Huyula}

\section{Pengetahuan Petani Terhadap Huyula}

Pengetahuan petani adalah pengetahuan yang diketahui oleh petani setelah mereka mengalami, menyaksikan, mengamati atau diajarkan, dan berkaitan dengan kearifan lokal Huyula. Jumlah soal mengenai kearifan lokal Huyula adalah 4 soal dan diberikan kepada 42 responden. Bentuk soal yang diberikan adalah soal pertanyaan dengan jawaban ya (Tahu), dan tidak (Tidak Tahu). Berdasarkan data lapang yang diperoleh, pengetahuan petani padi sawah terhadap Huyula dikelompokkan menjadi dua kategori yaitu pengetahuan rendah dan pengetahuan tinggi, dengan akumulasi skor untuk pengetahuan rendah (6-8) dan akumulasi skor untuk pengetahuan tinggi (9-10).

Seluruh responden atau sebanyak 100\% mengetahui arti dari Huyula yang berarti bekerja secara bersama-sama atau bergotong-royong. Terdapat sebesar $92,9 \%$ petani yang mengetahui sistem pengolahan lahan dan penanaman padi secara Huyula. Hal ini lebih besar daripada persentase petani yang memiliki pengetahuan dalam sistem pengolahan lahan dan penanaman padi secara "Ti' ayo" (Tabel 3).

Berkaitan dengan sistem pengolahan lahan dan penanaman padi secara "Ti'ayo". Petani yang tidak mengetahui kearifan lokal tersebut memiliki persentase yang cukup besar yaitu sebesar 38,1\%. Petani yang tidak mengetahui kearifan lokal Ti'ayo tersebut pada umumnya berasal kelompok petani muda yang tidak pernah mengalamai $\mathrm{Ti}$ ayo dan belum pernah mendengar cerita-certia tentang "Ti ayo". Hal ini dikarenakan kegaitan-kegiatan "Ti ayo" lebih dahulu pudar di masyarakat dibandingkan dengan Huyula. "Ti ayo" pudar sekitar pertengahan orde baru sedangkan Huyula dalam pertanian mulai hilang pada periode reformasi. Hal ini menyebabkan "Ti ayo" sudah tidak tersosialisasikan lagi di masyarakat khususnya petani-petani muda.

\section{Sikap Petani Terhadap Huyula}

Jumlah soal untuk mengukur sikap petani terhadap kearifan lokal Huyula adalah 4 soal dan diberikan kepada 42 responden. Bentuk soal yang diberikan adalah soal pertanyaan dengan jawaban sangat tidak setuju, tidak setuju, setuju, sangat setuju. Berdasarkan data lapang yang diperoleh, sikap petani padi sawah terhadap Huyula dikelompokkan menjadi dua kategori yaitu sikap negatif dan sikap positif, dengan akumulasi skor untuk sikap negatif(48) dan akumulasi skor untuk pengetahuan tinggi (913). Petani yang senang dengan sistem pengolahan lahan pertanian secara Huyula beranggapan bahwa Huyula dapat mempererat rasa kekeluargaan di antara petani. Fakta ini sesuai dengan kutipan pernyataan petani sebagai berikut

"Kita suka sekali itu ba pajeko dengan
Huyula, gagah dia, soalnya bisa bekeng
torang jadi kuat depe persaudaraan, baru
baHuyula itu bekeng torang pe pekerjaan ba
pajeko lahan jadi ringan, daripada bapajeko 
Jurnal Penyuluhan, Maret 2014 Vol. 10 No. 1

Tabel 6 Hubungan antara Usia terhadap Pengetahuan, Sikap dan Perilaku Huyula Petani

\begin{tabular}{llcccc}
\hline & Usia & $\begin{array}{c}\text { Tingkat } \\
\text { Pengetahuan }\end{array}$ & Tingkat Sikap & Tingkat Perilaku \\
\hline Usia & Koefisien & 1,000 & 0,598 & 0,383 & 0,466 \\
& p-value & - & 0,000 & 0,012 & 0,002 \\
Keterangan & & Berhubungan Nyata & BerhubunganNyata & BerhubunganNyata \\
\hline
\end{tabular}

sendiri, pe lama sekali mau selesay" (Zainudin Sadu, 55)

"Saya senang sekali dengan sistem Huyula dalam pengolahan lahan, itu sistem yang bagus, soalnya hal itu dapat memperkuat tali persaudaraan, kedua Huyula dapat membantu meringankan pekerjaan dalam pengolahan lahan, berbeda dengan mengolah lahan secara sendiri-sendiri, hal itu tentunya membutuhkan waktu yang lama untuk dapat menyelesaikannya' (Zainudin Sadu, 55)

Petani yang tidak senang dengang pengolahan lahan secara Huyula memiliki persentase yang cukup besar yaitu tidak setuju sebesar 33,3\% dan sangat tidak setuju sebesar $4,8 \%$. Petani yang tidak setuju tersebut beranggapan bahwa biaya konsumsi yang dikeluarga untuk memberi makan peserta Huyula sama saja besarnya dengan upah pembajak yang menggunakan traktor, selain itu Huyula bersifat terikat karena terikat kontrak untuk harus bekerja untuk orang lain dalam periode hari tertentu. Fakta ini sesuai dengan kutipan pernyataan petani sebagai berikut.

"Bo sama saja mau pake Huyula dengan pake traktor, itu biaya mau kase makan pa orang sama saja dengan biaya upah traktor, tapi pake traktor lebih cepat, lebih hemat tenagä' (Haris Antuli, 40).

"Menurut saya sama saja antara Huyula dengan traktor; soalnya biaya konsumsi untuk orang yang bekerja secara Huyula sama saja besamya dengan upah traktor, justru menggunakan traktor pekerjaan lebih cepat dan efisien tenagä' (Haris Antuli, 40).

Pada pertanyaan kedua yang menanyakan tentang rasa senang atau ketertarikan petani terhadap sistem Huyula dalam kegiatan penanaman padi. Terdapat sebesar $57,1 \%$ petani yang setuju, $14,3 \%$ sangat setuju, $23,8 \%$ tidak setuju, dan $4,8 \%$ sangat setuju. Petani yang tidak senang dengan penanaman padi secara Huyula beranggapan bahwa dengan Huyula maka dapat menghilangkan mata pencaharian regu tanam. Fakta ini sesuai dengan pernyataan petani sebagai berikut:

"Sekarang kita kalo batanam so pake kelompok tanam, itu kelompok tanam nanti torang mo bayar, biasanya Rp 150.000/ pantango. Kalo so mo pake Huyula, atiolo itu kelompok tanam, so tidak mo dapa doi" (Hais Yunus, 44)

"Sekarang kalo saya menanam sudah menggunakan kelompok tanam, dan mereka biasanya dibayar sebesar $R p$ 150.000/ pantango. Kalau orang-orang masih menerapkan Huyula, kasian juga para kelompok tanam, mereka tidak dapat memperoleh penghasilan dari bekerja sebagai penanant" (Hais Yunus, 44)

Selain itu, dengan menggunakan Huyula terkadang bersifat tidak adil bagi petani yang mendapat giliran terakhir dalam penanaman padi. Petani yang mendapatkan giliran terakhir dapat berdampak bagi umur bibit yang semakin tua, umur bibit yang tua atau melewati 2 minggu dapat berpengaruh terhadap kualitas produksi padi yang dihasilkan oleh bibit tersebut. Fakta ini sesuai dengan pernyataan:

"Saya nyanda terlalu suka dengan Huyula itu, soalnya kasian petani yang mau dapat urutan terakhir, bisa-bisa dia punya bibit so mo kadaluarsa, kalo depe bibit so terlalu tua, nanti dia punya perbanyakan padinya sedikit, depe gabah sadiki' (Muhlis Ibrahim,44) 
Tabel 7 Hubungan Tingkat Pendapatan terhadap Pengetahuan, Sikap dan Perilaku Huyula Petani

\begin{tabular}{lll}
\hline & \multicolumn{2}{c}{ Tingkat Pendapatan } \\
\hline $\begin{array}{l}\text { Tingkat } \\
\text { Pengetahuan }\end{array}$ & Koefisien & 0,003 \\
& P-value & 0,987 \\
& Keterangan & Tidak Berhubungan \\
Tingkat Sikap & Koefisien & 0,035 \\
& $P$ - value & 0,826 \\
& Keterangan & Tidak Berhubungan \\
Tingkat Perilaku & Koefisien & $-0,006$ \\
& $P$ - value & 0,971 \\
& Keterangan & Tidak Berhubungan \\
\hline
\end{tabular}

"Saya enggak terlalu suka dengan Huyula, soalnya kasian dengan petani yang memperoleh urutan terakhir, bibit padi yang ia miliki bisa mengalami kadaluarsa, jika umur bibitnya terlalu tua, dapat membuat peranakan padinya menjadi sedikit dan gabahnya sedikit' (Muhlis Ibrahim, 44)

Pada pertanyaan ketiga yang menanyakan tentang pengolahan lahan saat ini dapat dilaksanakan secara Huyula. Terdapat sebesar $4,8 \%$ petani yang setuju, $59,5 \%$ tidak setuju, dan $35,7 \%$ sangat setuju. Petani yang tidak setuju dengan pengolahan padi secara Huyula beranggapan bahwa saat ini penggunaan teknologi traktor lebih efisien dan praktis, dan sulit untuk menemukan orang-orang yang dapat diajak ber-Huyula.

Pada pertanyaan keempat yang menanyakan tentang penanaman padi saat ini dapat dilaksanakan secara Huyula. Terdapat sebesar $16,7 \%$ petani yang setuju, 73,8\% tidak setuju, dan 9,5\% sangat tidak setuju. Petani yang tidak setuju dengan penanaman padi secara Huyula beranggapan bahwa saat ini orang-orang lebih memilih mengupah jasa kelompok tanam daripada harus menanam padi secara Huyula. Penggunaan kelompok tanam lebih praktis dan hemat tenaga, selain itu kelompok tanam juga berperan dalam memanen padi yang mereka tanam.

\section{Perilaku Petani terhadap Huyula}

Perilaku Petani terhadap Huyula adalah manifestasi dari sikap, aktivitas atau kegiatan yang dilakukan petani dalam hubungannya dengan kearifan lokal Huyula. Jumlah soal mengenai kearifan lokal Huyula adalah tiga soal dan diberikan kepada 42 responden. Bentuk soal yang diberikan adalah soal pertanyaan dengan jawaban tidak pernah (TP), pernah (P), jarang (J), setuju (S), dan sangat setuju (SS). Berdasarkan data lapang yang diperoleh, perilaku petani padi sawah terhadap Huyula dikelompokkan menjadi dua kategori yaitu perilaku rendah dan perilaku tinggi, dengan akumulasi skor untuk perilaku rendah (4-6) dan akumulasi skor untuk perilaku tinggi (7-8).

Sebanyak $64,3 \%$ petani sering mengikuti pembersihan saluran irigasi, 21,4\% jarang mengikuti, $11,9 \%$ pernah mengikuti, dan $2,4 \%$ petani tidak pernah ikut serta dalam kegiatan pembersihan saluran irigasi secara Huyula. Hal ini menunjukkan bahwa Huyula dalam kegiatan pembersihan saluran irigasi masih kuat di antara para petani. Fakta ini sesuai dengan pernyataan petani sebagai berikut.

"Biasanya kalo mau kase bersih saluran irigasi, torang mo karja sama-sama. Tanpa upah itu, torang ihlas bakarja, itu boleh mau bilang Huyula" (Heri Mile, 44).

"Biasanya dalam pembersihan saluran irigasi, kita bekerja bersama sama dalam melakukan pekerjaan tersebut, kita ihlas bekerja, hal itu juga bisa dibilang dengan Huyua" (Heri Mile, 44).

"Huyula disini tinggal kase bersih saluran irigasi, so tidak ada itu Huyula ba pajeko 
Tabel 8 Hasil Pengujian Hubungan antara Tingkat Pendidikan terhadap Pengetahuan, Sikap dan Perilaku Huyula Petani

\begin{tabular}{lll}
\hline & & Tingkat Pendidikan \\
\hline Tingkat Pengetahuan & Koefisien & 0,000 \\
& P - value & 1,000 \\
Tingkat Sikap & Keterangan & Tidak Berhubungan \\
& Koefisien & 0,114 \\
& P - value & 0,473 \\
Tingkat Perilaku & Keterangan & Tidak Berhubungan \\
& Koefisien & 0,000 \\
& P - value & 1,000 \\
& Keterangan & Tidak Berhubungan \\
\hline
\end{tabular}

dengn Huyula batanan‘ (Samin Rajak, 50).

"Huyula di sini hanya tersisa dalam
pembersihan saluran irigasi, sistem Huyula
dalampengolahan lahan dan juga penanaman
sudah tidak ada" (Samin Rajak, 50).

Pada pertanyaan mengenai kegiatan pengolahan lahan secara Huyula, terdapat sebesar $85,7 \%$ petani pernah melakukan Huyula dalam pengolahan lahan, dan 14\% tidak pernah melakukan kegiatan tersebut. Hal ini menunjukkan bahwa kegiatan pengolahan lahan secara Huyula pernah dialami oleh petani namun sudah tidak dilakukan lagi pada saat ini. Hal tersebut dikarenakan petani lebih memilih untuk mengupah pengolah lahan. Upah yang dikeluarkan biasanya sebesar Rp 200.000/ pantango, biaya tersebut sudah termasuk traktor, dan solar. Menggunakan traktor dalam pengolahan sawah lebih efiesien tenaga dan waktu jika dibandingkan dengan mengolah lahan menggunakan tenaga manusia secara Huyula.

Sebanyak $85,7 \%$ petani pernah melakukan kegiatan penanaman padi secara Huyula, sisanya yaitu $14,3 \%$ petani tidak pernah melakukan kegiatan tersebut. Hal tersebut menunjukkan bahwa sebagian besar petani sudah pernah melakukan kegiatan penanaman secara Huyula namun sekarang petani sudah tidak menerapak sistem tersebut. Hal ini dikarenakan sistem Huyula dalam penanaman saat ini telah berubah menjadi sistem upah. Terdapat kelompok tanam yang dapat disewa oleh petani untuk melakukan penanaman pada areal sawah yang ia miliki. Besar upah kelompok tanam bervariasi yaitu sekitar Rp 150.000 - Rp 200.000/pantango. Upah tersebut dibayar kepada ketua kelompok tanam, selanjutnya kelompok tanam tersebut yang akan membagikan upah tersebut secara adil kepada anggota semua anggota kelompok lainnya dengan perhitungan yang telah dibuat atau dilakukan sebelumnya. Hal ini untuk menghindari terjadinya perselisihan antar anggota kelompok.

\section{Hubungan Faktor Internal dan Eksternal terhadap Huyula}

\section{Hubungan Usia erhadap Pengetahuan, Sikap dan Perilaku Huyula Petani}

Usia adalah lamanya seseorang hidup yang dihitung semenjak ia lahir hingga ulang tahun terakhir sebelum penelitian ini dilakukan. Dalam penelitian ini, usia responden yang berupa petani padi sawah dibagi menjadi tiga yaitu petani muda (18-30 tahun), petani dewasa (31-50 tahun ) dan petani tua ( $>50$ tahun). Uji hubungan usia terhadap pengetahuan, sikap dan perilaku Huyula petani berusaha melihat hubungan di antara keempat variabel tersebut.

Usia petani terhadap pengetahuan, sikap dan juga perilaku Huyula para petani menunjukkan adanya hubungan $(p<0,05)$.Usia petani berhubungan dengan tingkat pengetahuan, sikap dan perilaku Huyula petani. Hasil tersebut menunjukkan bahwa perbedaan usia petani menyebabkan perbedaan terhadap tingkat pengetahuan, sikap dan perilaku Huyula petani.

Hasil uji antara usia dan tingkat pengetahuan menunjukkan bahwa ada hubungan antara kedua variable tersebut, yaitu dengan nilai probabilitas 
Tabel 9 Hasil Pengujian Hubungan antara Luas Lahan Garapan terhadap Pengetahuan, Sikap dan perilaku Huyula Petani

\begin{tabular}{lll}
\hline & & \multicolumn{1}{c}{ Luas Lahan Garapan } \\
\hline $\begin{array}{l}\text { Tingkat } \\
\text { Pengetahuan }\end{array}$ & Koefisien & 0,112 \\
& $P-$ value & 0,479 \\
& Keterangan & Tidak Berhubungan \\
Tingkat Sikap & Koefisien & $-0,076$ \\
& $P$-value & 0,633 \\
& Keterangan & Tidak Berhubungan \\
Tingkat Perilaku & Koefisien & $-0,213$ \\
& $P-$ value & 0,175 \\
& Keterangan & Tidak Berhubungan \\
\hline
\end{tabular}

$0,000(p<0,05)$ dan nilai koefesien sebesar 0,589 menunjukkan hubungan yang sedang atau cukup berarti $(0,400-0,599)$ di antara dua buah variabel yang diuji. Hasil tersebut juga menunjukkan adanya hubungan yang searah, yaitu semakin tinggi usia petani maka semakin tinggi tingkat pengetahuan petani terhadap Huyula. Hal ini karena petani yang memiliki usia yang tinggi (semakin tua) cenderung memiliki tingkat pengetahuan yang tinggi pula terhadap kearifan lokal Huyula.

\section{Hubungan Tingkat Pendapatan terhadap Pengetahuan, Sikap dan Perilaku Huyula Petani}

Tingkat pendapatan responden adalah jumlah penghasilan secara keseluruhan dari hasil pertanian yang dijual dalam setahun terakhir, ditambah dengan penghasilan sampingan (non pertanian) yang diperoleh dalam setiap bulan. Ratarata pendapatan responden yaitu sebesar 26,2 juta/ tahun. Pendapatan responden bervariasi menjadi tiga golongan yaitu petani yang memiliki pendapatan rendah, sedang dan tinggi. Terdapat hubungan antara tingkat pendapatan terhadap pengetahuan, sikap dan perilaku Huyula petani $(p>0,05)$. Hal ini dikarenakan nilai probabilitas pada ketiga variable dependen lebih besar dari 0,005. Hal ini menunjukkan bahwa besar kecilnya pendapatan para petani tidak berhubungan dengan terhadap pengetahuan, sikap dan perilaku terhadap Huyula. Hal ini disebabkan oleh tinggi atau rendahnya pendapatan ekonomi yang mereka peroleh hanya akan berpengaruh terhadap kesejahteraan secara ekonomi tetapi tidak berhubungan dengan perubahan pengetahuan ataupun keterampilan mereka mengenai huyula.

\section{Hubungan Tingkat pendidikan terhadap Pengetahuan, Sikap dan Perilaku Huyula Petani}

Tingkat pendidikan merupakan jenjang pendidikan formal terakhir yang pernah ditempuh dan telah memperoleh kelulusan. Dalam penelitian ini, responden dibagi ke dalam tiga kategori berdasarkan tingkat pendidikan yaitu rendah, sedang dan tinggi. Petani yang memiliki pendidikan rendah yaitu petani yang hanya tamat bangku sekolah dasar, petani yang memiliki pendidikan sedang yaitu petani yang menyelesaikan pendidikan pada tingkat sekolah menengah pertama. Terdapat hubungan antara tingkat penddidikan terhadap pengetahuan, sikap dan perilaku Huyula petani $(p>0,05)$. Hal ini dikarenakan nilai probabilitas ketiga variable dependen lebih besar dari 0,005, tinggi rendahnya tigkat pendidikan petani petani tidak berhubungan dengan terhadap pengetahuan, sikap dan perilaku petani terhadap Huyula.

\section{Hubungan Luas Lahan Garapan terhadap Pengetahuan, Sikap dan Perilaku Huyula Petani}

Luas lahan garapan adalah luas lahan yang digarap (dikerjakan) oleh petani, dihitung dengan satuan $\mathrm{Ha}$ atau $\mathrm{m}^{2}$. Dalam penelitian ini luas lahan garapan petani padi sawah dibagi menjadi tiga kategori. Rata-rata luas lahan garapan responden dalam penelitian ini adalah 1,2 Ha. Terdapat hubungan signifikan luas lahan garapan terhadap pengetahuan, sikap dan juga perilaku Huyula 
Tabel 10 Hasil Pengujian Hubungan antara Intensitas Penyuluhan terhadap Pengetahuan, Sikap dan Perilaku Huyula Petani

\begin{tabular}{lll}
\hline & & Intensitas Penyuluhan \\
\hline Tingkat Pengetahuan & Koefisien & 0,708 \\
& $P$ - value & 0,000 \\
Keterangan & Berhubungan nyata \\
Tingkat Sikap & Koefisien & 0,760 \\
& $P$ - value & 0,000 \\
Tingkat Perilaku & Keterangan & Berhubungan nyata \\
& Koefisien & 0,420 \\
& $P$ - value & 0,006 \\
& Keterangan & Berhubungan nyata \\
\hline
\end{tabular}

dari petani $(\mathrm{p}>0,05)$. Hal ini dikarenakan nilai probabilitas ketiga variable dependen lebih besar dari 0,005. Hal ini menunjukkan bahwa tinggi atau rendahnya luas lahan garapan petani tidak berhubungan dengan terhadap pengetahuan, sikap dan perilaku petani terhadap Huyula.

Berdasarkan hasil uji tersebut, maka hipotesis penelitian yang berbunyi "Diduga semakin tinggi luas lahan garapan petani maka tingkat pengetahuan, sikap dan perilaku terhadap Huyula semakin tinggi." tidak dapat diterima. Hasil ini dikarenakan petani yang memiliki pengetahuan, sikap dan perilaku yang tinggi terhadap Huyula tersebar secara merata pada golongan petani yang memiliki luas lahan garapan yang rendah, sedang maupun yang memiliki luas lahan garapan yang tinggi.

\section{Hubungan Intensitas Penyuluhan terhadap Pengetahuan, Sikap dan Perilaku Huyula Petani}

Intensitas penyuluhan adalah tingkat keterlibatan petani kegiatan-kegiatan yang diselenggarakan oleh lembaga-lembaga atau organisasi penyuluhan. Penyuluhan lapang pertanian diDesaBongoime dilaksanakan oleh BalaiPenyuluhan Pertanian, Perikanan dan Kehutanan (BP3K) wilayah Kecamatan Tilongkabila, Kabupaten Bone Bolango. Kegiatan penyuluhan yang diselenggarakan oleh balai BP3K yaitu berupa pelatihan penggunaan benih, pelatihan penggunaan saprodi, pelatihan penggunaan pupuk organic, pelatihan penyusunan RDK/RDKK, pelatihan jadwal penghamburan, pelatihan tentang usaha pemupukan modal, dan pelatihan tentang administrasi kelompok tani.
Intensitas penyuluhan terhadap pengetahuan, sikap dan perilaku Huyula petani menunjukkan adanya hubungan $(p<0,05)$. Intensitas penyuluhan berhubungan dengan tingkat pengetahuan, sikap dan perilaku Huyula petani. Hasil tersebut menunjukkan bahwa perbedaan intensitas penyuluhan petani menyebabkan perbedaan terhadap tingkat kepuasan yang dirasakan masyarakatpengetahuan, sikap dan perilaku Huyula petani.

Hasil uji antara intensitas penyuluhan dan tingkat pengetahuan menunjukkan bahwa ada hubungan antara kedua variabel tersebut, yaitu dengan nilai probabilitas $0,000(\mathrm{p}<0,05)$ dan nilai koefesien sebesar 0,708 menunjukkan hubungan yang kuat $(0,600-0,799)$ diantara dua buah variabel yang diuji. Hasil tersebut juga menunjukkan adanya hubungan yang searah, yaitu semakin tinggi intensitas penyuluhan maka semakin tinggi tingkat pengetahuan petani terhadap Huyula. Hal ini karena petani yang memiliki intensitas penyuluhan tinggi cenderung memiliki tingkat pengetahuan yang tinggi pula terhadap kearifan lokal Huyula.

\section{Kesimpulan}

Huyula merupakan kerjasama sosial tanpa pamrih yang telah ada dan sejak dahulu dipraktekkan oleh para luluhur dan merupakan suatu sistem ekonomi yang terkoordinir maupun secara sukarela. Pada masyarakat Desa Bongoime, nilai-nilai Huyula diterapkan oleh masyarakat dalam berbagai aspek kehidupan. Nilai-nilai dari Huyula diwujudkan dalam berbagai kegiatan misalnya dalam kerja bakti pembersihan lingkungan pedesaan, pembuatan 
jalan, kematian, pembersihan saluran irigasi umum maupun kegiatan pertanian. Nilai-nilai Huyula sebagai suatu bentuk kearifan lokal di Desa Bongoime merupakan salah satu solusi yang membantu petani dalam kaitannya dengan pengelolaan sumberdaya pertanian padi sawah. Dalam pengelolaan sumber daya pertanian khususnya pertanian padi sawah di Desa Bongoime nilai-nilai Huyula terbagi menjadi dua wujud yaitu kegiatan Huyula dan Ti'ayoKearifan lokal ini pernah dialami oleh masyarakat pada periode sebelum reformasi. Namun saat ini, sistem Huyula dalam pengolahan lahan dan penanaman telah berubah menjadi sistem upah.

Masyarakat Desa Bongoime secara umum memiliki pengetahuan, sikap dan perilaku yang tinggi terhadap Huyula, meskipun Huyula dalam pertanian saat ini hanya diterapkan dalam proses pembersihan saluran irigasi. Pengetahuan petani terhadap Huyula berhubungan nyata dengan sikap dan perilaku petani.

Faktor usia dan intensitas penyuluhan berhubungan dengan pengetahuan, sikap dan perilaku petani terhadap Huyula. Semakin tinggi usia petani maka semakin tinggi pengetahuan, sikap dan perilaku petani terhadap Huyula. Hal ini pun sama terjadi terhadap intensitas penyuluhan petani, yaitu semakin tinggi intensitas penyuluhan petani maka semakin tinggi pengetahuan, sikap dan perilaku petani terhadap Huyula.

\section{Daftar Pustaka}

Ahimsa P. 2008. Ilmuwan Budaya dan Revitalisasi Keraifan Lokal Tantangan Teoritis dan Metodologis. Yogyakarta (ID): Fakultas Ilmu Budaya UGM.

Alwi O. 1958. Ceramah Penyuluhan Pertanian. Teks Ceramah bagi Para Mahasiswa pada tanggal 25 November 1958 di Fakultas Pertanian. UI. Bogor

Aulia TOS. 2012. Kearifan Lolak Dalam Pengelolaan Sumberdaya Air di Kampung Kuta. [Skripsi]. Bogor (ID): Institut Pertanian Bogor.

Cruz HS. 1961. FAO's Role in Rural Welfare, FAO of the UN. Rome, Halaman 119.

Duludu UATA. 2012. Pengembangan Model Pelatian Berbasis Kearifan Lokal Dalam Meningkatkan Profesionalisme Tutor Paket C di Kabupaten Bone Bolango. Unirvesitas
Pendidikan Indonesia. Repository. Upi. Edu

Farhan. 2012. Pengaruh Kearifan Lokal Dalam Pengelolaan Pantai terhadap Kunjungan Wisatawan. [Skripsi]. Bogor (ID): Institut Pertanian Bogor.

Hatu R. 2011. Perubahan Sosial Kultural Suatu Masyarakat Pedesaan. Jurnal Inovasi. 8(4) Desember 2011. Fakultas Ilmu Sosial Universitas Negeri Gorontalo.

Kamasan IO. 2003. Nyepi dan Awig-Awig dalam Pelestarian Fungsi Lingkungan. [Thesis]. [Internet]. [dapat diunduh dari: http://eprints. undip.ac.id]

Keraf AS. 2002. Etika Lingkungan. Jakarta (ID): Penerbit Buku Kompas.

Notoatmodjo S. 2003. Pendidikan dan Perilaku Kesehatan. Jakarta (ID): Rineka Cipta.

Padmanagara S. 1984. Membina Penyuluhan Pertanian. BPLPP. Jakarta (ID): Departemen Pertanian.

Ridwan NA. 2007. Landasan keilmuan kearifan lokal. [Jurnal]. [Internet] [dapat diunduh dari :http://ibda.files.wordpress.com/2008/04/2landasan-keilmuankearifanlokal. pdf.

Sairin S. 2006. "Yang Diingat dan Dilupakan, Yang Teringat dan Terlupakan: Social Memory dalam Studi Antropologi" dalam Ahimsa-Putra HS (ed). Esai-esai Antropologi Teori, Metodologi dan Etnografi. Yogyakarta (ID): Keppel Press.

Sartini. 2004. Menggali Kearifan Lokal Nusantara Sebuah Kajian Filsafat. Jurnal Filsafat : Agustus 2004. 37(2).

Sirait E. 2005. Pengelolaan Sumberdaya Berbasis Kemasyarakatan dan Kearifan Lokal Kasus Pengelolaan Cendana di Kabupaten Timor Tengah Selatan Provinsi Nusa Tenggara Timur. [Disertasi]. Sekolah Pasca sarjana. Bogor (ID): Institut Pertanian Bogor.

Tirsa O. 2012. Praktik-Praktik Kearifan Lokal dalam Pengelolaan Sumberdaya Pertanian Padi Sawah. [Skripsi]. Bogor (ID): Institut Pertanian Bogor. Van den Ban AW dan Hawkins HS. 1996. Agricultural Extention (second edition). Blackwell Science. Osney Mead. Oxford OX2 OEL 